\title{
HEALTH STATUS AND PHYSICAL FITNESS OF MINES RESCUE BRIGADESMEN
}

\author{
HANA TOMASKOVA ${ }^{1}$, ZDENEK JIRAK ${ }^{2}$, SAMUEL LVONCIK ${ }^{3}$, MAREK BUZGA ${ }^{2}$, VLADISLAVA ZAVADILOVA ${ }^{2}$, \\ and MICHAELA TRLICOVA ${ }^{2}$
}

${ }^{1}$ University of Ostrava, Ostrava, Czech Republic

Department of Epidemiology and Public Health, Faculty of Medicine

${ }^{2}$ University of Ostrava, Ostrava, Czech Republic

Department of Physiology and Pathophysiology, Faculty of Medicine

${ }^{3}$ Miners Hospital in Karvina, Karvina, Czech Republic

\begin{abstract}
Objectives: The aim of the study was to assess health status of regular and part-time mines rescue brigadesmen. Material and Methods: A group of 685 mines rescue brigadesmen was examined within the preventive testing - a basic internal, biochemistry and anthropometric examination, physical fitness testing. Results: The average age of the subjects was $41.96 \pm 7.18$ years, the average exposure in mining was $20 \pm 8.1$ years, out of that $11.95 \pm 7.85$ years as mines rescue brigadesmen. Elevated levels of total serum cholesterol (T-CH) and low-density lipoprotein cholesterol (LDL-CH) were found in over $1 / 2$ of the subjects. Systolic hypertension (systolic blood pressure (SBP) $\geq 140 \mathrm{~mm} \mathrm{Hg}$ ) was confirmed in 34\%, overweight (body mass index $(\mathrm{BMI}) \geq 25$ ) in $62.3 \%$ and obesity (BMI $\geq 30$ ) in $20.4 \%$ of the examined mines rescue brigadesmen. The metabolic syndrome was found in $15.2 \%$ of persons. The highest physical fitness was found in mines rescue brigadesmen and the lowest in mine officers. Limit values of maximum oxygen uptake $\left(\mathrm{VO}_{2 \max } / \mathrm{kg}\right) \mathrm{determined}$ by the management of the mine rescue station were not reached by every 3rd of all mines rescue brigadesmen. Compared with the control group of the Czech and Slovak population, the rescuers are taller, have greater BMI, higher percentage of body fat in all age categories and proportionally to that they achieve a higher maximum minute oxygen uptake; however, in relative values per kg of body weight their physical fitness is practically the same as that of the controls. Conclusions: The prevalence of risk factors of cardiovascular diseases and $\mathrm{VO}_{2 \max } / \mathrm{kg}$ in the group of the mines rescue brigadesmen is comparable with that in the general untrained Czech population.
\end{abstract}

Key words:

Metabolic syndrome, Cardiovascular diseases, Physical fitness, Coal mining

\section{INTRODUCTION}

The work of mines rescue brigadesmen belongs among highly physically demanding jobs. The energy expenditure of mines rescue brigadesmen during the work under model conditions in the mining environment is reported by various authors to range from 400 up to $700 \mathrm{~W}$; however, for short periods of time the value may be as high as around $1000 \mathrm{~W}$ [1-3]. The heart rate may occasionally climb to 200 beats per min [2,3]. In addition to the physical strain, the mines rescue brigadesmen are also exposed to psychological stress and often to nearly extreme heat stress, whereby their core body temperature can increase

The article is realized in the project of Student Grant Competition of University of Ostrava, Faculty of Medicine (SGS2/LF/OU2012).

Grant manager: prof. Zdenek Jirak, MD.

Received: September 30, 2014. Accepted: November 20, 2014.

Corresponding author: H. Tomaskova, University of Ostrava, Department of Epidemiology and Public Health, Faculty of Medicine, Syllabova 19, 703 00 Ostrava -

Zabreh, Czech Republic (e-mail: hana.tomaskova@osu.cz). 
up to values around $39^{\circ} \mathrm{C}[1,3]$. Working conditions are made still more severe if the work must be performed with breathing apparatus $[2,4,5]$.

Mine rescue work can therefore be carried out only by individuals completely healthy, physically fit and mentally stable and their health status must be regularly screened within regular preventive medical examinations. The preventive testing should include strain test for examination of physical fitness [6] and assessment whether mines rescue brigadesmen meet the efficiency criteria for individual age categories and jobs.

The aim of the study was to assess health status of regular and part-time mines rescue brigadesmen in the OstravaKarvina Coalfield (OKC), with particular reference to risk factors for cardiovascular diseases (CVD), and to assay their fitness in terms of their ability to pursue the profession of a mines rescue brigadesman in underground coal mines.

\section{MATERIAL AND METHODS}

During 2012 a group of 685 mines rescue brigadesmen was examined within the mandatory periodic preventive testing in cooperation with the Miners Hospital in Karvina. The group included both mines rescue brigadesmen and officers of the Central Mine Rescue Station in Ostrava and also part-time mines rescue brigadesmen who are the permanent staff of mining companies in the OKC.

The examination consisted of anamnesis questionnaire, basic internal examination including a resting electrocardiography (ECG) (12 leads), basic anthropometric and body composition testing. Percentage of fat (\% F) was determined by the bioelectrical impedance analysis (BIA) using tetrapolar monofrequency apparatus Omron BF 511. Biochemical tests included determination of total serum cholesterol (T-CH), high-density lipoprotein cholesterol (HDL-CH) and low-density lipoprotein cholesterol (LDL-CH), triacylglycerol (TAG) and fasting blood glucose. The presence of metabolic syndrome was evaluated according to American Heart Association/National Heart, Lung, and Blood Institute (AHA/NHLBI) criteria (2004) [7]. The metabolic syndrome was considered to be present if 3 out of the following criteria were fulfilled:

- systolic blood pressure (SBP) $\geq 130 \mathrm{~mm} \mathrm{Hg}$ or diastolic blood pressure $(\mathrm{DBP}) \geq 85 \mathrm{~mm} \mathrm{Hg}$ or the patient is treated for hypertension,

- waist $>94 \mathrm{~cm}$,

- glycemia $\geq 5.55 \mathrm{mmol} / \mathrm{l}$ or treated for diabetes mellitus,

- HDL-CH $\leq 1 \mathrm{mmol} / \mathrm{l}$,

- TAG $\geq 1.7 \mathrm{mmol} / \mathrm{l}$.

In all tested subjects, a continuous gradual test on a bicycle ergometer was performed up to maximum. The load was increased from the initial $25 \mathrm{~W}$ at minute intervals by $25 \mathrm{~W}$ up to maximum. Lung ventilation, oxygen uptake $\left(\mathrm{VO}_{2}\right)$ and carbon dioxide $\left(\mathrm{CO}_{2}\right)$ output were continuously recorded during the entire test by the apparatus OXYCON-PRO (Jaeger - Viasys, Germany). Also ECG was monitored continuously (all 12 leads). Blood pressure was measured at 2 min intervals on the left arm at heart level.

The anthropometric measures and indicators of physical fitness between specific professional groups of mines rescue brigadesmen were compared. The results of biochemical testing were compared with the normative values for the Czech population [8] and with the results of similar studies in various professions of male population in the Czech Republic [9]. The results of anthropometric examinations and the indicators of physical fitness of the mines rescue brigadesmen group are discussed in comparison with the testing of physical fitness of the Czech and the Slovak population in 1976 [10] and with the results of physical fitness study in the Australian mines rescue brigadesmen [11].

\section{STATISTICS}

Statistical analysis was performed using descriptive statistics, t-test, correlation analysis and multivariable linear 
regression. Statistical tests were evaluated at a significance level of 5\%. Statistical software Stata version 13 was used for data analysis [12].

\section{RESULTS}

The mean \pm standard deviation $(\mathrm{M} \pm \mathrm{SD})$ age of the group of mines rescue brigadesmen was $42 \pm 7.2$ years, the average height $178.2 \pm 6.6 \mathrm{~cm}$, the average weight $88.3 \pm 11.7 \mathrm{~kg}$, body mass index (BMI) $27.8 \pm 3.2$, percentage of fat $23.8 \pm 5.3 \%$ and lean body mass (LBM) was $66.9 \pm 6.8 \mathrm{~kg}$. The mean exposure reached in the mining industry was $20 \pm 8.1$ years, out of that $11.95 \pm 7.85$ years in the rescue profession. Professional and age composition of the group is shown in Table 1.

\section{Anamnesis data}

As much as $12.4 \%(\mathrm{~N}=85)$ of the personnel were treated for hypertension, of whom $29.2 \%$ were officers, $8.6 \%$ part-time mines rescue brigadesmen and $8 \%$ were regular mines rescue brigadesmen. Regular smoking was declared by $26.9 \%$ of rescuers, of whom the prevailing majority $(74.6 \%)$ smoked up to 10 cigarettes per day, $23.8 \%$ smoked from 11 to 20 cigarettes daily and only 3 people smoked more than 20 cigarettes a day. Most of the smokers were in the group of regular mines rescue brigadesmen, while fewest smokers were in the group of officers.
Sport activity of the whole study group was surprisingly low. Nearly $1 / 2$ of the study group (48.6\%) did not practice any sport or practiced sports only sporadically. Only $26.9 \%$ of the personnel practiced sport regularly, more often than twice a week, while $24.5 \%$ of the people practiced sport only once a week. The group of regular mines rescue brigadesmen was relatively most sport-active, while the group of officers was least sport-active.

\section{Results of physical fitness testing and biochemical testing}

Basic anthropometric characteristics and the results of physical fitness testing in the group of mines rescue brigadesmen are shown in Table 2. Compared with the control sample of the Czech and Slovak population from the year 1976 [10] the current rescuers are taller, have greater BMI, higher percentage of body fat in all age categories and proportionally to that, they achieve a higher maximum minute oxygen uptake, while in terms of relative values per $\mathrm{kg}$ of body weight, their physical fitness is practically the same (Table 2).

Table 3 represents the relative numbers of persons with overweight and obesity in the specific professional groups. Whereas the percentage of obese personnel was practically the same in the both groups of rescuers, the percentage of obese officers was significantly higher $(p=0.034)$. The number of obese individuals increased

Table 1. Age structure of the group of mines rescue brigadesmen

\begin{tabular}{lccccc}
\hline \multirow{2}{*}{\multicolumn{1}{c}{ Profession }} & \multicolumn{5}{c}{$\begin{array}{c}\text { Respondents } \\
(\mathrm{N}=685) \\
{[\mathrm{n}(\%)]}\end{array}$} \\
\cline { 2 - 6 } & $\begin{array}{c}21-29 \\
\text { years old }\end{array}$ & $\begin{array}{c}30-39 \\
\text { years old }\end{array}$ & $\begin{array}{c}40-49 \\
\text { years old }\end{array}$ & $\begin{array}{c}50-59 \\
\text { years old }\end{array}$ & total \\
\hline Regular mines rescue brigadesman & $4(2)$ & $72(37)$ & $109(55)$ & $12(6)$ & $197(100)$ \\
Part-time mines rescue brigadesman & $33(9)$ & $135(38)$ & $158(45)$ & $25(7)$ & $351(100)$ \\
Officer & $2(1)$ & $10(7)$ & $83(61)$ & $42(31)$ & $137(100)$ \\
Total & $39(6)$ & $217(32)$ & $350(51)$ & $79(12)$ & $685(100)$ \\
\hline
\end{tabular}


Table 2. Basic anthropometric characteristics and the results of physical fitness testing of mines rescue brigadesmen and comparison with Czech and Slovak population

\begin{tabular}{|c|c|c|c|c|c|c|c|}
\hline \multirow{2}{*}{ Age group } & \multicolumn{3}{|c|}{$\begin{array}{l}\text { Mines rescue brigadesmen } \\
\text { (2012) }\end{array}$} & \multicolumn{3}{|c|}{$\begin{array}{c}\text { Czech and Slovak population } \\
\text { (1976) [10] }\end{array}$} & \multirow{2}{*}{$\mathrm{p}$} \\
\hline & $\begin{array}{l}\text { respondents } \\
{[\mathrm{n}]}\end{array}$ & M & SD & $\begin{array}{l}\text { respondents } \\
{[\mathrm{n}]}\end{array}$ & M & SD & \\
\hline 21-29 years old & 39 & & & 100 & & & \\
\hline height [cm] & & 179.8 & 8.6 & & 177.00 & 6.80 & 0.0457 \\
\hline weight $[\mathrm{kg}]$ & & 84.6 & 13.9 & & 75.80 & 8.90 & $<0.001$ \\
\hline body fat [\%] & & 21.9 & 6.2 & & 13.50 & 4.40 & $<0.001$ \\
\hline LBM $[\mathrm{kg}]$ & & 65.6 & 8.6 & & 63.20 & 6.20 & 0.1183 \\
\hline $\mathrm{BMI}\left[\mathrm{kg} / \mathrm{m}^{2}\right]$ & & 26.1 & 3.3 & & 24.19 & 1.90 & 0.0013 \\
\hline $\mathrm{VO}_{2 \max }[1 / \mathrm{min}]$ & & 3.7 & 0.6 & & 3.24 & 0.51 & $<0.001$ \\
\hline $\mathrm{VO}_{2 \text { max }}[\mathrm{ml} / \mathrm{kg} / \mathrm{min}]$ & & 44.0 & 4.7 & & 43.20 & 8.00 & 0.4451 \\
\hline 30-39 years old & 217 & & & 100 & & & \\
\hline height [cm] & & 178.8 & 6.3 & & 175.80 & 6.80 & $<0.001$ \\
\hline weight $[\mathrm{kg}]$ & & 88.0 & 11.5 & & 78.40 & 8.90 & $<0.001$ \\
\hline body fat [\%] & & 23.0 & 5.4 & & 16.00 & 4.40 & $<0.001$ \\
\hline LBM $[\mathrm{kg}]$ & & 67.3 & 6.5 & & 64.80 & 6.20 & 0.0015 \\
\hline BMI $\left[\mathrm{kg} / \mathrm{m}^{2}\right]$ & & 27.5 & 3.2 & & 25.40 & 2.90 & $<0.001$ \\
\hline $\mathrm{VO}_{2 \max }[1 / \mathrm{min}]$ & & 3.6 & 0.5 & & 3.01 & 0.50 & $<0.001$ \\
\hline $\mathrm{VO}_{2 \max }[\mathrm{ml} / \mathrm{kg} / \mathrm{min}]$ & & 40.9 & 4.2 & & 39.30 & 8.00 & 0.0685 \\
\hline 40-49 years old & 350 & & & 100 & & & \\
\hline height [cm] & & 177.9 & 6.3 & & 174.20 & 6.80 & $<0.001$ \\
\hline weight $[\mathrm{kg}]$ & & 88.6 & 11.2 & & 79.10 & 8.90 & $<0.001$ \\
\hline body fat [\%] & & 24.2 & 4.9 & & 18.00 & 4.50 & $<0.001$ \\
\hline LBM $[\mathrm{kg}]$ & & 66.8 & 6.4 & & 65.80 & 6.20 & 0.1836 \\
\hline BMI $\left[\mathrm{kg} / \mathrm{m}^{2}\right]$ & & 28.0 & 3.0 & & 26.10 & 1.90 & $<0.001$ \\
\hline $\mathrm{VO}_{2 \max }[1 / \mathrm{min}]$ & & 3.3 & 0.4 & & 2.75 & 0.51 & $<0.001$ \\
\hline $\mathrm{VO}_{2 \max }[\mathrm{ml} / \mathrm{kg} / \mathrm{min}]$ & & 37.9 & 4.4 & & 35.80 & 8.00 & 0.0136 \\
\hline 50-59 years old & 79 & & & 100 & & & \\
\hline height [cm] & & 176.8 & 7.3 & & 172.50 & 6.80 & 0.0001 \\
\hline weight $[\mathrm{kg}]$ & & 89.6 & 12.7 & & 79.50 & 8.90 & $<0.001$ \\
\hline body fat [\%] & & 25.1 & 5.3 & & 15.60 & 4.50 & $<0.001$ \\
\hline LBM [kg] & & 66.7 & 7.9 & & 66.70 & 6.30 & 0.9999 \\
\hline BMI $\left[\mathrm{kg} / \mathrm{m}^{2}\right]$ & & 28.6 & 3.5 & & 26.70 & 1.90 & $<0.001$ \\
\hline $\mathrm{VO}_{2 \max }[1 / \mathrm{min}]$ & & 3.0 & 0.5 & & 2.49 & 0.51 & $<0.001$ \\
\hline $\mathrm{VO}_{2 \text { max }}[\mathrm{ml} / \mathrm{kg} / \mathrm{min}]$ & & 34.3 & 5.7 & & 32.60 & 8.00 & 0.1075 \\
\hline
\end{tabular}

$\mathrm{M}$ - mean; SD - standard deviation; LBM - lean body mass; $\mathrm{BMI}$ - body mass index; $\mathrm{VO}_{2 \max }$ - maximum oxygen uptake. 
Table 3. Persons with a normal weight, an overweight and obesity

\begin{tabular}{|c|c|c|c|c|}
\hline \multirow[t]{2}{*}{ Profession } & \multicolumn{4}{|c|}{$\begin{array}{c}\text { Respondents } \\
(\mathrm{N}=685) \\
{[\mathrm{n}(\%)]}\end{array}$} \\
\hline & $\begin{array}{c}\text { normal weight } \\
(\mathrm{BMI}<25)\end{array}$ & $\begin{array}{c}\text { overweight } \\
(\mathrm{BMI}=25-29.9)\end{array}$ & $\begin{array}{c}\text { obesity } \\
\text { (BMI } \geq 30)\end{array}$ & total \\
\hline Regular mines rescue brigadesman & $36(18.3)$ & $124(62.9)$ & $37(18.8)$ & $197(100)$ \\
\hline Part-time mines rescue brigadesman & $68(19.4)$ & $219(62.4)$ & $64(18.2)$ & $351(100)$ \\
\hline Officer & $14(10.2)$ & $84(61.3)$ & $39(28.5)$ & $137(100)$ \\
\hline Total & $118(17.2)$ & $427(62.3)$ & $140(20.4)$ & $685(100)$ \\
\hline
\end{tabular}

BMI - body mass index.

with age ( $p=0.015)$. The overweight was found in $56.4 \%$ of the age category $<29$ years in the whole study group and obesity in $10.3 \%$ of rescuers. In the age category $>50$ years, $58.2 \%$ of mines rescue brigadesmen were affected by overweight and $29.1 \%$ by obesity.

The results of biochemical testing and resting values of blood pressure in the group of mines rescue brigadesmen are shown in Table 4. The high percentage of mines rescuers brigadesmen achieved values of T-CH (54.2\%), LDL$\mathrm{CH}(65.2 \%)$ and TAG (42.5\%) beyond the range of the normative values valid for the Czech population [8].
Systolic blood pressure exceeding $139 \mathrm{~mm} \mathrm{Hg}$ was found in $29.4 \%$ of persons and diastolic blood pressure higher than $89 \mathrm{~mm} \mathrm{Hg}$ was detected in 140 persons (20.4\%). New-detected cases of hypertension included systolic hypertension in $148(21.6 \%)$ and diastolic hypertension in $95(13.9 \%)$ of the rescuers. Metabolic syndrome was found in $15.2 \%$ of persons.

The multivariate analysis showed high statistically significant positive correlation between maximum oxygen uptake $\left(\mathrm{VO}_{2 \max }\right)$, BMI and sport activity. Conversely, $\mathrm{VO}_{2 \max }$ was in statistically significant negative correlation with

Table 4. Biochemical testing and resting values of blood pressure in the group of mines rescue brigadesmen

\begin{tabular}{|c|c|c|c|c|c|}
\hline \multirow[b]{2}{*}{ Variable } & \multirow[b]{2}{*}{ M } & \multirow[b]{2}{*}{ SD } & \multirow[b]{2}{*}{$\begin{array}{c}\text { Upper reference } \\
\text { level }\end{array}$} & \multicolumn{2}{|c|}{ Respondents } \\
\hline & & & & $\begin{array}{c}\text { total } \\
{[\mathrm{n}]}\end{array}$ & $\begin{array}{c}\text { with the value } \\
\text { poorer than } \\
\text { the norm } \\
{[\mathrm{n}(\%)]}\end{array}$ \\
\hline $\mathrm{T}-\mathrm{CH}[\mathrm{mmol} / \mathrm{l}]$ & 5.26 & 1.20 & $\leq 5.00$ & 681 & $369(54.2)$ \\
\hline LDL-CH [mmol/l] & 3.44 & 0.97 & $\leq 3.00$ & 679 & $443(65.2)$ \\
\hline HDL-CH [mmol/l] & 1.23 & 0.32 & $>1.00$ & 681 & $162(23.8)$ \\
\hline TAG [mmol/l] & 1.90 & 1.33 & $\leq 1.70$ & 680 & $289(42.5)$ \\
\hline Glycemia [mmol/l] & 5.01 & 0.93 & $\leq 5.55$ & 680 & $102(15.0)$ \\
\hline $\mathrm{SBP}[\mathrm{mm} \mathrm{Hg}]$ & 129.10 & 11.97 & $\geq 140.00$ & 680 & $200(29.4)$ \\
\hline DBP [mm Hg] & 80.20 & 7.68 & $\geq 90.00$ & 681 & $141(20.7)$ \\
\hline
\end{tabular}

T-CH - total serum cholesterol; LDL-CH - low-density lipoprotein cholesterol; HDL-CH - high-density lipoprotein cholesterol; TAG - triacylglycerol; SBP - systolic blood pressure; DBP - diastolic blood pressure.

Other abbreviations as in Table 2. 
Table 5. Multivariate linear regression on the predictors of physical fitness $\left(\mathrm{VO}_{2 \max }[1 / \mathrm{min}]\right)$ of mines rescue brigadesmen

\begin{tabular}{|c|c|c|c|c|}
\hline \multirow{2}{*}{ Variable } & \multicolumn{4}{|c|}{ Multivariate linear regression } \\
\hline & coefficient $\beta$ & $\mathrm{p}$ & & \\
\hline Body mass index & 0.096 & $<0.001$ & 0.080 & 0.111 \\
\hline Age [years] & -0.027 & $<0.001$ & -0.032 & -0.023 \\
\hline Fat $[\%]$ & -0.019 & $<0.001$ & -0.028 & -0.010 \\
\hline \multicolumn{5}{|l|}{ Smoking } \\
\hline no & 0.000 & (base) & & \\
\hline yes & -0.114 & 0.001 & -0.179 & -0.048 \\
\hline \multicolumn{5}{|l|}{ Sport activity } \\
\hline no & 0.000 & (base) & & \\
\hline yes & 0.174 & $<0.001$ & 0.116 & 0.232 \\
\hline \multicolumn{5}{|l|}{ Profession } \\
\hline professional rescuer & 0.000 & (base) & & \\
\hline voluntary rescuer & -0.118 & 0.001 & -0.185 & -0.050 \\
\hline technician & -0.243 & $<0.001$ & -0.331 & -0.155 \\
\hline Constant & 2.394 & $<0.001$ & 2.060 & 2.728 \\
\hline
\end{tabular}

Base - base category; CI - confidence interval.

age, smoking, and percentage of fat. Significantly large age adjusted differences in physical fitness were found between the individual professions. The fitness declined from the highest in regular mines rescue brigadesmen through medium in part-time mines rescue brigadesmen to the lowest in the officers (Table 5).

\section{Physical fitness and risk factors}

\section{of cardiovascular diseases}

Table 6 presents correlations between the indicators of physical fitness $\left(\mathrm{VO}_{2 \text { max }}\right.$ and $\mathrm{VO}_{2 \text { max }} / \mathrm{kg}$ ), percentage of body fat and the value of BMI on one hand and the level of blood lipids and level of blood pressure on the other hand. A significant negative correlation between $\mathrm{VO}_{2 \text { max }}$ and T-CH, LDL-CH, TAG, SBP and DBP, and a significant positive correlation with HDL-CH and the ratio HDL-CH/T-CH was found. The percentage of body fat and BMI showed a significant positive correlation with T-CH, LDL-CH, TAG, SBP and DBP, and a negative correlation with HDL-CH and the ratio HDL-CH/T-CH.

\section{DISCUSSION AND CONCLUSIONS}

The cardiovascular diseases are the major cause of death in the Czech Republic and are also on a top among causes of long-term sickness [13]. The reasons are seen primarily in the life style, inappropriate quantitative and qualitative composition of the diet, increased mental stress [14] and a lack of time for relaxation and sport activities.

Chaloupka and Wolfová (2008) examined a sample of 6387 male Czech population of various professions at the prevailing age of 36-42 years [9]. The highest prevalence of cardiovascular risk factors was found in drivers, fire-fighters and the construction workers, while the lowest in administrative staff and military professionals. A high percentage of individuals with the levels of T-CH (54.2\%) and TAG (42.5\%) exceeding the norms is consistent with the levels reported by Chaloupka and Wolfová in the most vulnerable professions of fire-fighters and construction workers [9].

Obesity is generally considered to be a significant risk factor for cardiovascular disease. The percentage of body 
Table 6. Correlation between the indicators of physical fitness and percentage of body fat and risk factors of cardiovascular diseases

\begin{tabular}{lcccc}
\hline & \multicolumn{4}{c}{ Correlation coefficient } \\
\cline { 2 - 4 } \multicolumn{1}{c}{ Parameter } & $\mathrm{VO}_{2 \max }$ & $\mathrm{VO}_{2 \mathrm{max}} / \mathrm{kg}$ & fat & BMI \\
\hline $\mathrm{T}-\mathrm{CH}[\mathrm{mmol} / \mathrm{l}]$ & $-0.123^{*}$ & $-0.266^{*}$ & $0.208^{*}$ & $0.172^{*}$ \\
$\mathrm{LDL}-\mathrm{CH}[\mathrm{mmol} / \mathrm{l}]$ & $-0.102^{*}$ & $-0.251^{*}$ & $0.229^{*}$ & $0.190^{*}$ \\
$\mathrm{HDL}-\mathrm{CH}[\mathrm{mmol} / \mathrm{l}]$ & 0.075 & $0.112^{*}$ & $-0.201^{*}$ & $-0.238^{*}$ \\
$\mathrm{TAG}[\mathrm{mmol} / \mathrm{l}]$ & 0.044 & $-0.237^{*}$ & $0.239^{*}$ & $0.223^{*}$ \\
$\mathrm{HDL}-\mathrm{CH} / \mathrm{T}-\mathrm{CH}$ & 0.034 & $0.276^{*}$ & $-0.310^{*}$ & $-0.303^{*}$ \\
$\mathrm{SBP}[\mathrm{mm} \mathrm{Hg}]$ & 0.028 & $-0.211^{*}$ & $0.229^{*}$ & $0.197^{*}$ \\
DBP [mm Hg] & 0.016 & $-0.244^{*}$ & $0.252^{*}$ & $0.221^{*}$ \\
\hline
\end{tabular}

Abbreviations as in Table 2 and 4.

$* \mathrm{p}<0.05$.

fat, BMI and number of obese persons increased significantly with age in all groups of mines rescue brigadesmen, but the highest increase was noted in the group of officers. The most of obese individuals regardless of age were identified, as expected, in the group of officers (28.5\%), the least in part-time mines rescue brigadesmen and regular mines rescue brigadesmen $(18.2 \%, 18.8 \%$, respectively). The number of obese persons in the group of officers exceeds the national average of male 2008 population $(23.9 \%)$, is the same as the national averages of European countries with the highest percentage of obesity (Greece $-27.9 \%$, and Scotland -26.6\%), [15] but is lower than the percentage of obese Czech drivers (45\%) [9].

In comparison with the 2005 Czech population average [13] the average value of SBP in the total group of mines rescue brigadesmen $(129.1 \mathrm{~mm} \mathrm{Hg})$ was identical. The average value of T-CH $(5.26 \mathrm{mmol} / \mathrm{l})$ in the group of mines rescue brigadesmen was slightly lower than the national average. Comparing the group of mines rescue brigadesmen with the group of fire-fighters [9], the mines rescue brigadesmen achieved more favorable levels both of SBP and T-CH. The same prevalence of metabolic syndrome as in our mines rescue brigadesmen $(15.2 \%)$ was found by Donovan et al. in American fire-fighters [16].
A higher prevalence of metabolic syndrome (20\%) in various professions of American male and female population was indicated by Levis et al. [17].

During the recent years, an increasing number of references have reported a positive correlation between obesity and low capability of the cardiopulmonary system and premature death from cardiovascular disease [18-25]. Bucksch et al. (2010) investigated the effect of physical activity on mortality in a group of 3724 men and 3445 women aged 30-69 years [18]. Physical activity decreased mortality of both sexes in persons with normal weight, the same as in persons with overweight and obesity compared to the control group. The results of the study demonstrate the prevalence of physical activity over weight reduction. The faster decline of age related cognitive function in persons with low value of $\mathrm{VO}_{2 \text { max }}$ was pointed out by Wendel et al. [26].

Good physical fitness is an important precondition for the performance of some physically demanding occupations, in particular of rescue brigades, such as mine rescuers, fire-fighters and others. Physical fitness is declining with age by about $1 \%$ per year both in untrained and in trained individuals. Regarding job retention, it is important for rescuers to keep good physical fitness necessary 
for the effective performance of their profession until retirement [6,27]. As shown by numerous studies, a hard physical work itself is not enough to achieve a good physical fitness $[11,25]$. Work in the industry does not have a character of training load. Training effect can be reached only from physical activity of a dynamic nature and sufficient intensity performed by large muscle groups at least 3 times a week for 20 min [28-30]. Also walking or bicycling to work can bring beneficial effect on physical fitness, but not gardening or work at a cottage [31]. Smoking, on the other hand, is associated with a lower physical fitness [31,32].

A comparison of physical fitness between different populations is difficult due to the considerable differences attributable to the character and arrangement of the strain tests. Based on our experience, the highest values of $\mathrm{VO}_{2 \max }$ are reached in continuous gradual tests on a treadmill or a bicycle ergometer in which the load is increased in one minute intervals up to a maximum. The values lower by $5-7 \%$ are reached in loads with the particular grades duration of 2-3 min, while the results of the indirect methods might differ in the same tested persons in relationship to the number of grades used by 10 and even more percent $[29,33]$.

The most recent data on physical fitness of the Czech and Slovak adult population was published in the 70 s of the last century [10]. In comparison with the control Czech and Slovak population sample from the year 1976 [10], the contemporary mines rescue brigadesmen are taller and heavier and reach higher levels of $\mathrm{VO}_{2 \text { max }}$ in the individual age categories. In the relative values per $\mathrm{kg}$ of body weight, the physical fitness of the current mine rescuers does not differ from the Czech and Slovak population in 1976.

The same conclusion is valid for the present population aged 17-20 that is taller, heavier and has proportionally better physical fitness in comparison with the population of the same age from the year 1976. However, in the relative values per $\mathrm{kg}$ of body weight, the physical fitness of both populations is identical [34].

Comparable anthropometric values and physical fitness detected by extrapolation of the last grade of the step-test in Australian mines rescue brigadesmen were found by Stewart et al. [11]. Rather lower values of $\mathrm{VO}_{2 \text { max }}$ detected by the indirect method in the Indian miners $(42.4 \pm 2.03 \mathrm{ml} / \mathrm{kg}$ for the age group 20-29 and $34.2 \pm 3.38 \mathrm{ml} / \mathrm{kg}$ for the group 50-59 years), have been reported by Saha et al. [35]. Comparable values of $\mathrm{VO}_{2 \max } / \mathrm{kg}$ were indicated using linear extrapolation of sub-maximal values in a large population of American men and women aged $18-59$ by Lewis et al. [17].

Cardio-pulmonary fitness varied according to occupation. Professions with the lowest physical activity at work (administrative staff) included the highest number of individuals with a low fitness; in contrast, the highest values of $\mathrm{VO}_{2 \text { max }} / \mathrm{kg}$ were found in the construction workers $\left(49.5 \mathrm{ml} / \mathrm{kg}\right.$ ) [17]. Even higher values of $\mathrm{VO}_{2 \text { max }}$ found by maximum gradual test on a bicycle ergometer $(53 \mathrm{ml} / \mathrm{kg})$ in mountain rescuers aged $45 \pm 8.9$ were reported by Callender et al. [36]. The highest values of $\mathrm{VO}_{2 \text { max }} / \mathrm{kg}$ that are reached in the top high endurancetrained sportsmen varied around $80-90 \mathrm{ml} / \mathrm{kg}$ [29]. On the other hand, reports are accessible suggesting a potential risk of more frequent prevalence of atrial fibrillation in high-endurance-trained sportsmen [37,38].

The work of mine rescuers demands oxygen uptake ranging from $1.12 \pm 0.3$ to $2.16 \pm 0.6 \mathrm{l} / \mathrm{min}$ during emergency situations in mines, depending on the task being performed [1]. But in short term periods it may reach up to around 3 liters per min [2]. This corresponds to the value of $\mathrm{VO}_{2 \max } / \mathrm{kg} \geq 38 \mathrm{ml} / \mathrm{min}$ for an average rescuer who is $180 \mathrm{~cm}$ tall and has the total body weight of $80 \mathrm{~kg}$, $\% \mathrm{~F} \leq 20 \%, \mathrm{LBM} 64 \mathrm{~kg}$ and BMI $\leq 25$. The limit quoted above was not fulfilled by $30 \%$ of the total group of rescuers. It is necessary to implement measures intended to improve health status and physical fitness of mine rescuers, 
such as changes in lifestyle and dietary habits, including regular endurance training as part of the training program. According to Kampmann et al. (1977) a regular training is necessary for keeping a required physical efficiency during the whole productive age of a rescuer, and the intensity of the load during the training must be comparable with the load during an actual intervention [3].

\section{REFERENCES}

1. Hardcastle SG, Reardon FD, Kenny GP, Allen C. Assessing the work intensity of mine rescue activities and its relevance in applying heat stress management protocols. In: Panigrahi DC, editor. Mine ventillation. Proceedings of the 9th International Mine Ventilation Congress; 2009 Nov 10-13; New Delhi, India. New Delhi: Oxford \& IBH Publishing; 2009. p. 1-13.

2. Jirak Z, Lojova E. [Results of tests of physical fitness of mine rescue workers and their working exertion in a model situation]. Prac Lek. 1979;31(2):43-8. Czech.

3. Kampmann B, Bresser G, Piekarski C. Stress and strain of mine rescue teams during a standard training procedure. Appl Occup Environ Hyg. 1997;12(12):952-6, http://dx.doi.or g/10.1080/1047322X.1997.10390634.

4. Harzbecker K, Krause M, Mährlein W, Schettler R. [Longterm stress examinations under hypoxia in mine rescue workers]. Z Gesamte Inn Med. 1980;35(15):615-9. German.

5. Varley F. Study of heat stress exposures and interventions for mine rescue workers. Trans Soc Min Metal Explor. 2004;316:133-42.

6. Piekarski C. [Ergospirometry: A suitable method for evaluating work capacity in occupational medicine?]. Z Kardiol. 1994;83 Suppl. 3:173-7. German.

7. Grundy SM, Brewer HB Jr., Cleeman JI, Smith SC Jr., Lenfant C; National Heart, Lung, and Blood Institute; et al. Definition of metabolic syndrome: Report of the National Heart, Lung, and Blood Institute/American Heart Association conference on scientific issues related to definition. Arterioscler Thromb Vasc Biol. 2004;24(2):e13-8, http://dx.doi. org/10.1161/01.ATV.0000111245.75752.C6.
8. Soška V, Zima T, Freidecký B, Franeková J, Buryška J, Palička V, et al. [Common recommendations of the Czech Society of Clinical Biochemistry and the Czech Atherosclerosis Society for unifying the evaluation limits of blood lipids and lipoproteins for adult population]. Klin Biochem Metab. 2010;1:45-6. Czech.

9. Chaloupka J, Wolfová K. [Risk of cardiovascular diseases in selected professions]. Prac Lek. 2008;60(2):51-60. Czech.

10. Seliger V, Bartunek Z. [Mean values of various indices of physical fitness in the investigation of Czechoslovak population aged 12-55 years. International Biological Programme. Results of Investigations 1968-1974]. Praha: CSTV; 1976. Czech.

11. Stewart IB, McDonald MD, Hunt AP, Parker TW. Physical capacity of rescue personnel in the mining industry. J Occup Med Toxicol. 2008;3:22, http://dx.doi.org/10.1186/ 1745-6673-3-22.

12. Stata (Stata Statistical Software: Release 13.0) [computer program]. Stata Corporation; 2013.

13. Cardiovascular diseases [Internet]. The WHO Global Info Base; 2011 [cited 2014 Feb 1]. Available from: https://apps.who.int/infobase/Comparisons.aspx?1=\&Node $\mathrm{Val}=$ GBD_10_mo.cc.104\&DO=1\&DDLReg $=$ ALL $\&$ DDL Sex $=1 \&$ DDLAgeGrp $=$ All_Ages $\& D D L Y e a r=2004 \& D D L$ Method $=$ INTMDQUA $\& D D L C a t e N u m=6 \&$ DDLMapsize $=800 \times 480 \&$ DDLMapLabels $=$ none $\&$ DDLTmpRangBK $=1$ 37.7521\&DDLTmpColor $=-3342388$.

14. Brunner EJ, Chandola T, Marmot MG. Prospective effect of job strain on general and central obesity in the Whitehall II Study. Am J Epidemiol. 2007;165(7):828-37, http:// dx.doi.org/10.1093/aje/kwk058.

15. Global Prevalence of Adult Obesity [Internet]. International Association for the Study of Obesity; 2012 [cited 2014 Feb 1]. Available from: http://www.worldobesity.org/ site_media/uploads/2012_accounts.pdf.

16. Donovan R, Nelson T, Peel J, Lipsey T, Voyles W, Israel RG. Cardiorespiratory fitness and the metabolic syndrome in firefighters. Occup Med. 2009;59(7):487-92, http://dx.doi. org/10.1093/occmed/kqp095. 
17. Lewis JE, Clark JD 3rd, LeBlanc WG, Fleming LE, Cabán-Martinez AJ, Arheart KL, et al. Cardiovascular fitness levels among American workers. J Occup Environ Med. 2011;53(10):1115-21, http://dx.doi.org/10.1097/ JOM.0b013e31822cfe8e.

18. Bucksch J, Schlicht W. [Is mortality reduced by physical activity in normal- and overweight men and women?]. Dtsch Z Sportmed. 2010;61(3):72-8. German.

19. Crespo CJ, Palmieri MR, Perdomo RP, Mcgee DL, Smit E, Sempos CT, et al. The relationship of physical activity and body weight with all-cause mortality: Results from the Puerto Rico Heart Health Program. Ann Epidemiol. 2002;12(8):543-52, http://dx.doi.org/10.1016/S10472797(01)00296-4.

20. Kesaniemi YK, Danforth E Jr., Jensen MD, Kopelman PG, Lefèbvre P, Reeder BA. Dose-response issues concerning physical activity and health: An evidence-based symposium. Med Sci Sports Exerc. 2001;33(6 Suppl):S351-8.

21. Kodama S, Saito K, Tanaka S, Maki M, Yachi Y, Asumi M, et al. Cardiorespiratory fitness as a quantitative predictor of all-cause mortality and cardiovascular events in healthy men and women: A meta-analysis. JAMA. 2009;301(19):2024-35, http://dx.doi.org/10.1001/ jama.2009.681.

22. Koster A, Harris TB, Moore SC, Schatzkin A, Hollenbeck AR, van Eijk JT, et al. Joint associations of adiposity and physical activity with mortality: The National Institutes of Health-AARP Diet and Health Study. Am J Epidemiol. 2009;169(11):1344-51, http://dx.doi.org/10.1093/aje/ kwp053.

23. Leitzmann MF, Park Y, Blair A, Ballard-Barbash R, Mouw T, Hollenbeck AR, et al. Physical activity recommendations and decreased risk of mortality. Arch Intern Med. 2007;167(22):2453-60, http://dx.doi.org/10.1001/arch inte.167.22.2453

24. Talbot LA, Morell C, Metter EJ, Fleg JL. Comparison of cardiorespiratory fitness versus leisure time physical activity as predictors of coronary events in men aged $\leq 65$ years and > 65 years. Am J Cardiol. 2002;89(10):1187-92, http:// dx.doi.org/10.1016/S0002-9149(02)02302-0.

25. Tuxworth W, Nevill AM, White C, Jenkins C. Health, fitness, physical activity, and morbidity of middle aged male factory workers. I. Br J Ind Med. 1986;43(11):733-53.

26. Wendell CR, Gunstad J, Waldstein SR, Wright JG, Ferrucci L, Zonderman AB. Cardiorespiratory fitness and accelerated cognitive decline with aging. J Gerontol A Biol Sci Med Sci. 2014 Apr;69(4):455-62, http://dx.doi.org/10. 1093/gerona/glt144.

27. Prieto JA, González V, del Valle M, Nistal P. The influence of age on aerobic capacity and health indicators of three rescue groups. Int J Occup Saf Ergon. 2013;19(1):19-27.

28. Gram B, Holtermann A, Søgaard K, Sjøgaard G. Effect of individualized worksite exercise training on aerobic capacity and muscle strength among construction workers - A randomized controlled intervention study. Scand J Work Environ Health. 2012;38(5):467-75, http://dx.doi.org/10.5271/ sjweh.3260.

29. Hollmann W. [High and continuous performance of the athletes]. München: J.A. Barth; 1963. German.

30. American College of Sports Medicine (ACSM). ACSM's guidelines for the exercise testing and prescription. 9th ed. Philadelphia, PA: Wolters Kluwer/Lippincott Williams \& Wilkins; 2014.

31. Jirák Z, Šimíček J, Tomášková H, Bužga M, Zavadilová V, Čermáková Z, et al. [The development of physical fitness and general health state of the male and female population in North-Moravian region at the age of 45 to 60 years over the last 25 years]. Ceske Prac Lek. 2004;5(3):107-16. Czech.

32. Conway TL, Cronan TA. Smoking, exercise, and physical fitness. Prev Med. 1992;21(6):723-34, http://dx.doi. org/10.1016/0091-7435(92)90079-W.

33. Jirak Z, Rozvadovska S, Coufalova H. [Comparison of different methods of the individual indicators obtained in the investigation of the work load]. Prac Lek. 1974;26(6):202-6. Czech.

34. Jirák Z, Šimíček J, Bužga M, Tomášková H, Křenková M. [Trend of fitness and selected anthropological 
characteristics of the young population in the north Moravian region (Czech Republic) in the past 25 years]. Anthropologie. 2003;41(3):263-76. Czech.

35. Saha R, Dey NC, Samanta A, Biswas R. Maximum aerobic capacity of underground coal miners in India. J Environ Public Health. 2011;2011:232168, http://dx.doi. org/10.1155/2011/232168.

36. Callender N, Ellerton J, MacDonald JH. Physiological demands of mountain rescue work. Emerg Med J. 2012;29 (9):753-7, http://dx.doi.org/10.1136/emermed-2011-200485.
37. Baldesberger S, Bauersfeld U, Candinas R, Seifert B, Zuber M, Ritter M, et al. Sinus node disease and arrhythmias in the long-term follow-up of former professional cyclists. Eur Heart J. 2008;29(1):71-8, http://dx.doi.org/10.1093/eurheartj/ehm555.

38. Mont L, Elosua R, Brugada J. Endurance sport practice as a risk factor for atrial fibrillation and atrial flutter. Europace. 2009;11(1):11-7, http://dx.doi.org/10.1093/europace/ eun289.

This work is available in Open Access model and licensed under a Creative Commons Attribution-NonCommercial 3.0 Poland License - http://creativecommons.org/ licenses/by-nc/3.0/pl/deed.en. 